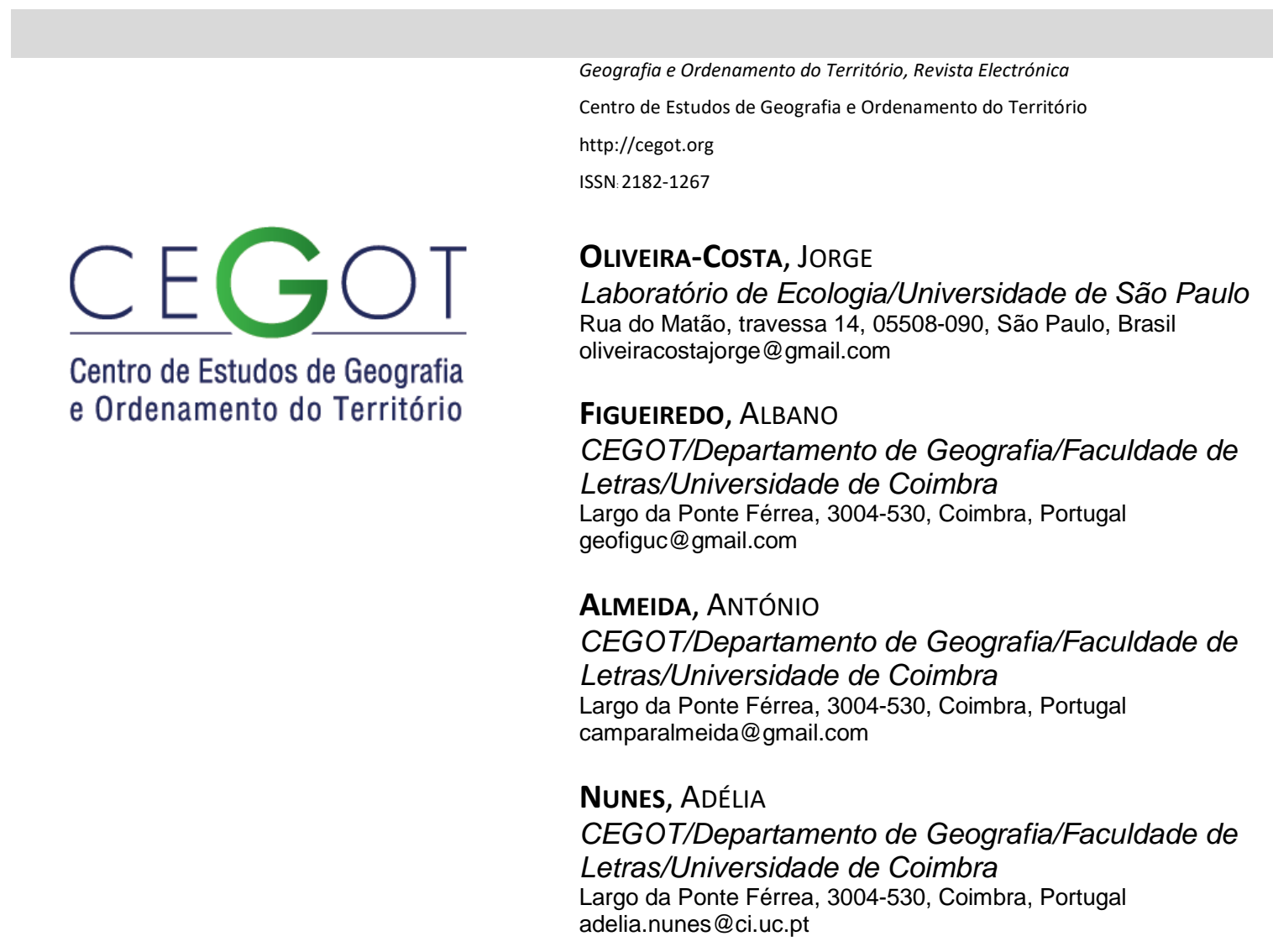

\title{
Caracterizando as invasões por Acácias Australianas na Bacia do Rio Arouce desde 1960 usando a distribuição das espécies, a história do uso do solo e as condicionantes físicas - implicações à invasibilidade
}

Characterizing the Acacia invasions in Arouce River (Lousã, Portugal) since 1960 using species distribution, land cover change and environment physical characters - implications for invasibility

Referência: Oliveira-Costa, Jorge et al. (2016). Caracterizando as invasões por Acácias Australianas na Bacia do Rio Arouce desde 1960 usando a distribuição das espécies, a história do uso do solo e as condicionantes físicas - implicações à invasibilidade. Revista de Geografia e Ordenamento do Território (GOT), n.o 10 (dezembro). Centro de Estudos de Geografia e Ordenamento do Território, p. 241-265, dx.doi.org/10.17127/got/2016.10.012

\section{RESUMO}

Os resultados sobre a invasividade na Bacia do Rio Arouce (Oliveira-Costa \& Souza, 2015) sugeriram que a colonização da área pelas Acácias está a ocorrer por uma possível via: matriz no setor intermédio com propagação sentido baixo curso via corredores ripários. Observada a invasividade local (graus de densidade/cobertura), as condições ambientais para as Acácias na área de estudo parecem ser favoráveis (invasibilidade). Este estudo é 
abordado por meio da análise das condições ambientais, partindo da informação da distribuição das espécies e dos atributos do meio físico. O método adotado inclui análise de imagens orbitais e de cartografias do uso do solo. Nos últimos 50 anos, as duas Acácias presentes na Bacia do Rio Arouce ( $A$. dealbata e $A$. melanoxylon) tem expandido progressivamente seus alcances, sob padrão estruturado pelas condições locais.

Palavras-Chave: Análise espacio-temporal. Condições ambientais. Plantas invasoras. SIG.

\section{ABSTRACT}

The results about invasiveness in the Arouce Watershed (Oliveira-Costa \& Souza, 2015), have suggested that the colonization of the region by the Acacia occur in a possible way: coming from the central area and disseminating to lower stream of the Arouce River. According the local invasiveness, the environmental conditions for Acacias in the study area are favorable (invasibility). This study is approached by analyzing the environmental conditions, through informations about species distributions and physical elements. The applied methods include analysis of orbital images and land cover maps. In the last 50 years, the two Acacias in the study area ( $A$. dealbata and $A$. melanoxylon) have been improving their local range, under patterns promoted by local conditions.

Keywords: Spatial-temporal analysis. Environmental conditions. Invasive plants. GIS.

\section{Introdução}

Tem-se observado nos estudos de EEI (Espécies Exóticas Invasoras) a necessidade de uma cooperação interdisciplinar (entre geografia, ecologia, genética, zoologia), visando alcançar desde traços potencializadores das espécies à invasão (Teoria da Invasividade) (Elton, 1958; Pysek et. al., 1995; Williamson, 1996), até traços fragilizadores do meio (Teoria da Invasibilidade) (Elton, 1958; Lockwood et. al., 2007). Nessa cooperação, a Geografia Física contribui: 1. verificando o padrão da complexidade do fenómeno: distribuição, ocupação e interação das EEl; 2. avaliando se o padrão está estruturalmente determinando pelas condições locais (fatores): estrutura da paisagem, ocorrência de incêndios, condicionantes físicas (invasibilidade); 3. predizendo o potencial invasor das espécies a partir da análise da diversidade biótica (consequências): densidade, cobertura, sociabilidade (invasividade). No trabalho anterior concentrado na invasividade (Oliveira-Costa \& Souza, 2015), a Bacia do Rio Arouce foi enquadrada em contexto de alto grau da invasão: fase 'exponencial' do processo, etapa 'tornando-se uma peste', espécies em grau de risco 'estabelecidas', 'alto' potencial 
invasor. Aqui será apresentado o quadro da invasibilidade, significativo para entendimento dos fatores da invasividade ligados a dinâmica e fragilidade do meio na Bacia do Rio Arouce.

Os impactes causados por EEI tem aumentado rapidamente, o que tem tornado a invasão biológica um problema global (Vavilov, 1992; Vitousek et. al., 1997; Simberloff \& Rejmànek, 2011), sobretudo em razão da potencial naturalização das EEI dentro de novas regiões (Shigesada \& Kawasaki, 1997), onde as espécies formam populações numerosas e autosustentáveis, promovendo disturbios de natureza ecológica, económica e social (IUCN, 1999). Assim, uma das primeiras preocupações nos estudos de EEl é determinar quais fatores promovem o sucesso da invasão (Guo, 2006). Uma das teorias centrais em invasão biológica defende que as alterações nos usos do solo podem agir como promotoras da invasão, em ação conjunta com elementos de ordem natural (dinâmica hidrológica, tipo de relevo, condições climáticas) (Fridley, 2011; Henderson et al., 2006; Rejmànek, 2011), e antrópica (desenvolvimento económico, crescimento populacional, abandono da terra) (Pimentel et. al., 2005).

A temporalidade e espacialidade na caracterização das invasões biológicas exigem informações advindas das condições ambientais (McDonald, 2003), sobretudo dos fluxos dos condicionantes estruturadores da paisagem e demais eventos físico-geográficos (Lockwood et. al., 2007), que podem agir como fatores determinantes tanto da invasividade quanto da invasibilidade, influenciando a extensão, duração, intensidade e o tempo de ocorrência desses fenómenos. Não obstante, apesar das implicações em termos de invasibilidade, dados das condições ambientais pouco predizem aspetos do potencial invasor das EEI (Watts, 1971), pois são pobre preditores das consequências das invasões. Entretanto, de posse dos dados da invasividade é possível estimar a invasibilidade (Fridley, 2011), onde a taxa de densidade das EEI poderá refletir a vulnerabilidade do meio. O modelo teórico por trás dessa abordagem trata da oportunidade dos ecossistemas, disponibilidade de recursos e plasticidade fenotípica (Levine et al., 2003; Gallien et al., 2010), e é estimado pela distribuição das EEI e sua densidade populacional, onde espécies com alta plasticidade são mais inclinadas ao estabelecimento, sobretudo a partir do favorecimento das condições locais tais como usos do solo, coberto vegetal, ocorrências de incêndios, condicionantes físicas (Henderson et al., 2006). Os fluxos dos caracteres estruturadores da paisagem podem liberar recursos, o que permitirá oportunidades de 
invasão, onde as EEI serão capazes de manter populações viáveis, dada as perturbações naturais e antropogênicas.

O Modelo Teórico da Invasão Biológica (Pysek et al., 1995; Rejmànek, 2011; Williamson, 1996; Richardson et al., 2006; Richardson \& Pysek, 2011) define para o processo: 1. etapas (1. introduzindo-se; 2. estabelecendo-se; 3. tornando-se uma peste); 2. graus de risco das EEI (1. introduzida/importada, 2. estabelecida, 3. transformadora) e potencial invasor (alto, médio, baixo), 3. fases de estabelecimento (lenta, exponencial). As três etapas das invasões (introduzindo-se, estabelecendo-se, tornando-se uma peste) estão relacionadas ao tempo para colonização das EEl e determinam seus graus de risco. Na etapa (1) os padrões de concentração dos recursos e os efeitos topográficos serão determinantes na expansão das espécies, onde a estrutura da paisagem poderá facilitar a dispersão linear via corredores ripários do habitat ou vias de acesso (Oliveira-Costa, 2014) na etapa (2) os padrões de distribuição geográfica (alto, médio, baixo curso) serão determinantes para sobrevivência dos propágulos das EEI (Pereira \& Figueiredo, 2015; Oliveira-Costa \& Souza, 2015), podendo surgir uma segunda ordem de estabelecimento de populações, distante do local original da colonização e facilitada dado o grau de fragmentação dos ecossistemas; na etapa (3) a configuração do habitat (altitude, declive, exposição) poderá facilitar a reprodução sustentável das EEI (Oliveira-Costa \& Souza, 2015), onde a combinação entre a estrutura da paisagem e a taxa de crescimento das populações poderão favorecer a propagação, alcançando um grau transformador, com impactos potencialmente irreversíveis.

O foco deste trabalho é uma análise espacio-temporal das mudanças no uso do solo, no geral, e uma avaliação da contribuição destas alterações para a ocorrência de invasões biológicas. A análise do uso do solo no passado e no presente é significativa para investigar três das principais questões da pesquisa: 1) compreensão dos locais onde as mudanças no uso do solo ocorreram; 2) avaliação das taxas destas mudanças; 3) relação entre as alterações no uso do solo e o histórico das invasões. A análise do uso do solo no presente é especialmente importante por revelar informações espaciais sobre a perda e/ou ganho de novas superfícies pelas EEI com a entrada/saída de elementos de risco. Procura-se caracterizar as invasões por Acácias Australianas na Bacia do Rio Arouce nos últimos 50 anos, fazendo a articulação entre informações da distribuição das espécies, história do uso do solo, e condicionantes físicas (figura 1), a fim de revelar e discutir as especificidades nas relações entre o processo da invasão e as condições ambientais. 


\section{Estudo das conseqüências da invasão}

- Presença/abundância de EEI (potencial invasor)

- Grau de ocupação (resposta a disturbios do meio)

- Grau de sociabilidade (dispersão, vigor competitivo)

- Grau de densidade (produção de propágulos)

- Grau de cobertura (capacidade de re/colonização)
GOT, n.o 10 - Revista de Geografia e Ordenamento do Território (dezembro de 2016)

GOT, nr. 10 - Geography and Spatial Planning Journal (December 2016)

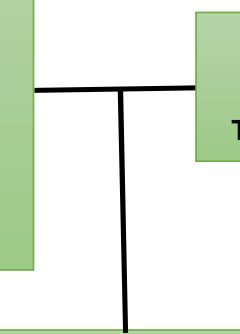

\section{Invasividade}

Traços que potencializam EEI

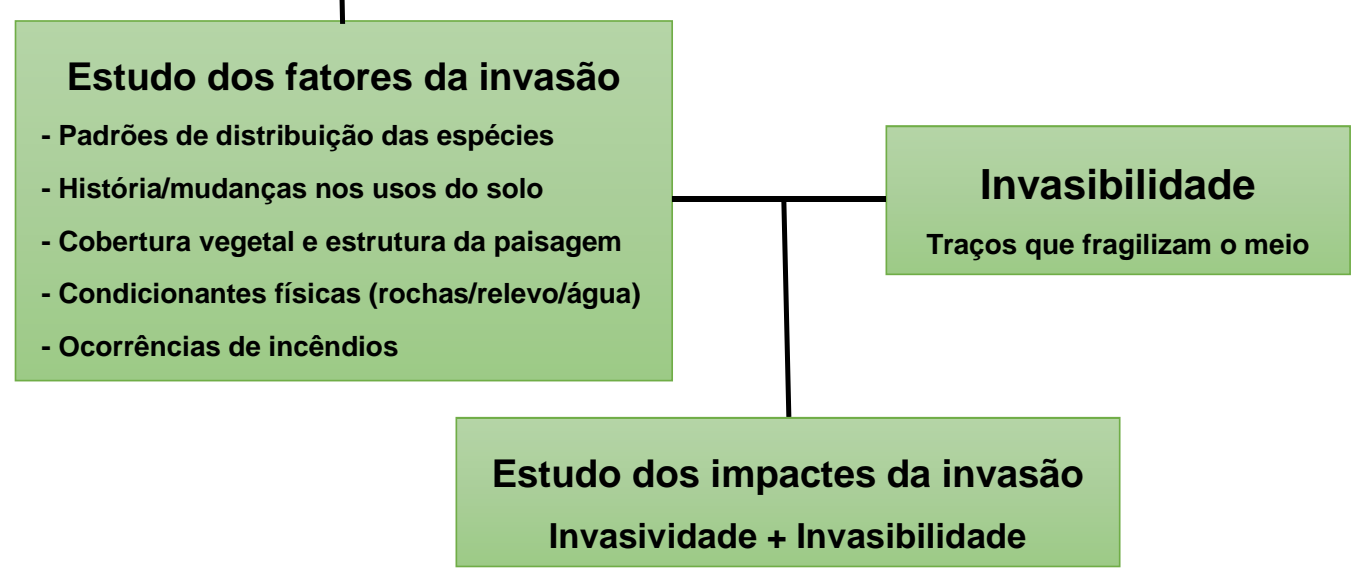

Figura 1 - Árvore dos parâmetros para caracterização das invasões biológicas por Acácias Australianas entre 1960-2011 na Bacia Hidrográfica do Rio Arouce (Região Centro/Lousã)

\section{2. Área em estudo e condições de invasividade}

A unidade de estudo, a Bacia do Rio Arouce (Figura 2), possui área de 7.300 hectares, com topografia de cotas entre 54 metros (baixo curso) até 1200m (cabeceiras), com fraco declive no sector terminal e declive acentuado no sector intermédio $\left(40^{\circ}-50^{\circ}\right)$. A cidade da Lousã compreende o centro da área de estudo e o epicentro das invasões. O principal solo é o cambissolo, com predominância de rochas de xistos e granitos da Serra da Lousã. Áreas residenciais e industriais distribuem-se pela planície sedimentar. Áreas rurais e áreas urbanas descontínuas distribuem-se pelas encostas do Vale do Arouce.

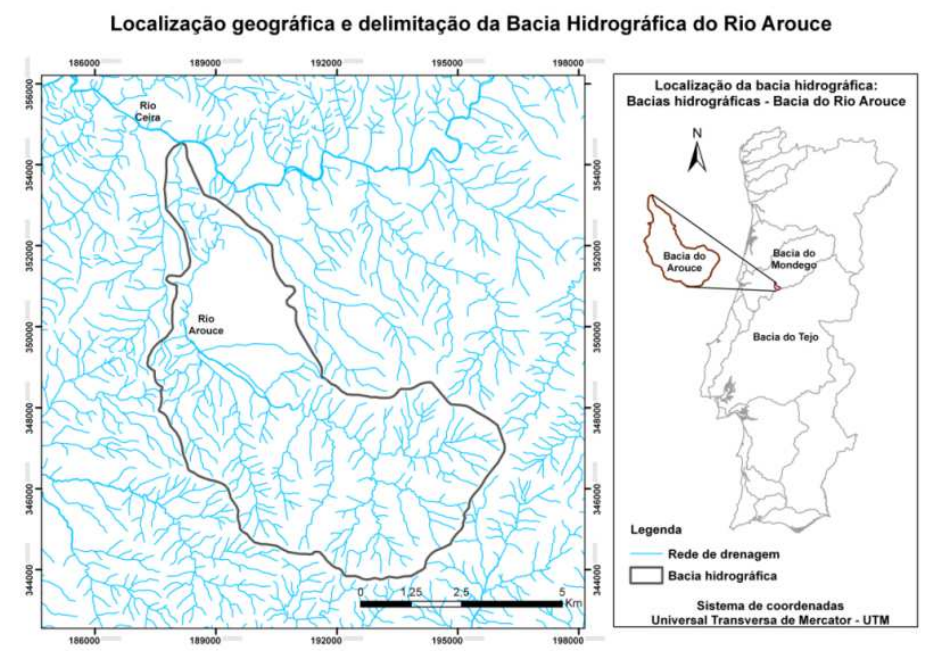

Figura 2 - Localização da Bacia do Rio Arouce. Fonte: Serviço Cartográfico do Exército, 1950 
Em termos de ocupação do solo, a área é caracterizada pela presença de zonas florestais (40\% da área de estudo), e pela baixa densidade residencial (13\% da área de estudo). Há significante coberto vegetal de florestas não nativas ( $55 \%$ do coberto vegetal), e florestas com espécies do género Pinus L. (35\% do coberto vegetal). As zonas florestais não nativas dentro da área de estudo concentram-se, sobretudo, no sector intermédio (área úmida), ao longo dos cursos d'água e vias de acesso, e estão representadas por espécies do género Eucalyptus L'Hér, e por duas espécies do género Acacia (Tourn.) Mill. (A. dealbata e $A$. melanoxylon). Quanto às espécies nativas, são representativas quatro espécies do género Quercus (Q. robur, Q. faginea; Q. faginea subsp. broteroi; Q. suber), além da presença conspícua das espécies Laurus nobilis e Rusco aculeati. Ainda, nas áreas dos sectores terminal e cabeceiras estão presentes Calluno ullicetea, Ulici minoris, Ericetum umbellatae, Salix atrocinerea, Prunus lusitanica, Ilex aquifolium, Osmunda regalis, Viburnum tinus, Rhododendron ponticum, Arbutus unedo.

Foram avaliados, quantitativamente e qualitativamente (Oliveira-Costa \& Souza, 2015), aspectos sobre a distribuição e abundância das duas espécies de Acácias Australianas presentes na Bacia do Rio Arouce, partindo do pressuposto teórico que características da distribuição e da densidade de EEI podem certamente serem vistas como preditores da invasividade de espécies de sucesso (Williamson, 1996), como é o caso da A. dealbata e da A. melanoxylon na Bacia do Rio Arouce. Acacia dealbata Link 1822 e Acacia melanoxylon R. Br. são árvores endêmicas da Austrália, com características comuns como a fixação de N2, adaptação ao fogo, banco de sementes de longa duração (até 10 anos) e autopolinização pelo sistema reprodutivo, além da independência de zonas antropizadas (em qualquer estágio de vida), o que tem permitido uma propagação cosmopolita dessas espécies durante o último século ao redor do mundo.

A superfície potencial com risco alto de ocupação é de 2025ha (sector intermédio), correspondendo a $28 \%$ da superfície da Bacia do Rio Arouce; a superfície com risco médio alcança área de 2200ha (sector terminal) e corresponde a 30\% da área de estudo; a superfície com risco baixo de ocupação é de 3056ha e corresponde a $42 \%$ da superfície da Bacia do Rio Arouce. Desse modo, as categorias de maior risco de propagação das Acácias (alto e médio risco) concentram-se em $58 \%$ da superfície da Bacia Hidrográfica do Rio Arouce, somando 4225 ha do total de aproximadamente 7300 ha da área de estudo (OliveiraCosta \& Souza, 2015). 
Em conivência com o mapa das unidades ambientais da bacia (Figura 3), foram desdobrados três cenários diferentes das invasões na Bacia do Rio Arouce. No alto curso (sector cabeceiras), onde o topo atinge $1200 \mathrm{~m}$ e o declive $48^{\circ}$, foi detectado o contexto mais recente das invasões por Acácias na área de estudo. É correspondente ao sector dos menores valores de densidade e cobertura das espécies ( $n$ 으 de espécies $<35$ por parcelas de $200 \times 200 m)$. A A. dealbata apresenta-se com indivíduos isolados, com baixo valor do grau de ocupação ( $5 \%$ por parcelas de $200 \times 200 \mathrm{~m})$, enquanto a $A$. melanoxylon é menos freqüente, com alto percentual de presença não identificada.

No médio curso (sector intermédio) a densidade de indivíduos é a mais importante da área de estudo, sendo caracterizado como o sector mais antigo das invasões por Acácias na Bacia do Rio Arouce. É correspondente a matriz das espécies e sector da introdução, com os maiores valores de densidade e cobertura das Acácias ( $n$ - de espécies $>400$ por parcelas de 200x200m). A A. dealbata apresenta-se sob grandes manchas, com elevados valores para o grau de ocupação ( $>75 \%$ por parcelas de $200 \times 200 m$ ), em morfologia dos declives acentuados da bacia $\left(40^{\circ}-50^{\circ}\right)$, e altitudes entre $400 \mathrm{~m}$ e $700 \mathrm{~m}$.

No baixo curso (sector terminal) a distribuição das espécies é mais pontual que no médio curso. Nesse sector a invasão é proveniente de dispersão do setor intermédio (mais elevado topograficamente), com valores médios de densidade e cobertura das espécies ( $\mathrm{n}$ - de espécies <250 por parcelas de $200 \times 200 m$ ). A A. dealbata apresenta-se sob pequenas manchas, com valores médios para o grau de ocupação (5-25\% por parcelas de 200×200m), sob o domínio dos baixos declives e altitudes da bacia.

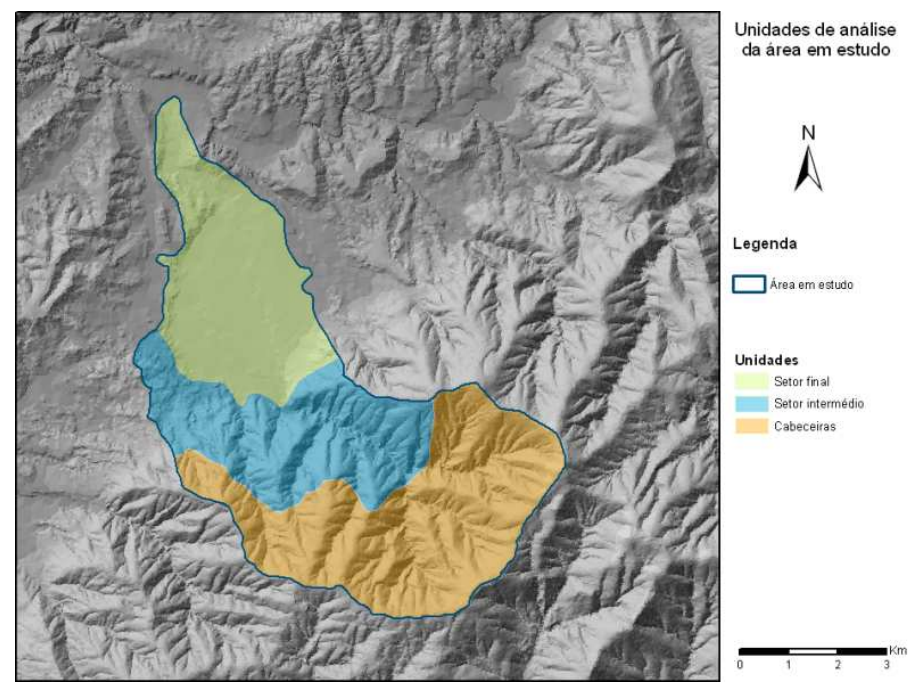

Figura 3 - Compartimentação da área de estudo em três unidades ambientais distintas 


\section{Aplicação da metodologia}

A abordagem para análise do uso do solo como base para a subsequente avaliação das invasões por espécies não nativas, requer a combinação de diferentes métodos. Para análise da história do uso do solo, a metodologia aplicada baseou-se em cinco passos:

1. Estabelecimento da escala temporal de análise;

2. Estabelecimento das classes de uso do solo;

3. Análise das mudanças temporo-espaciais dos usos do solo;

4. Análise das mudanças temporo-espaciais das invasões;

5. Análise integrada: uso do solo (incluindo incêndios) - invasões - condicionantes físicas

\subsection{Escala temporal de análise}

Há, pelo menos, duas considerações importantes a serem inferidas no âmbito do estabelecimento da escala temporal para análise das mudanças no uso e ocupação do solo, pelas quais o trabalho está concentrado: a) quais os documentos cartográticos estão disponíveis para as condições do uso do solo no passado, e b) qual escala temporal é razoável considerando as invasões biológicas no passado e no presente.

Seguindo uma determinada ordem para comparar os resultados, a escala temporal de análise deve ser escolhida de acordo com a existência de contextos no presente que apresentem ligações com os eventos ocorridos no passado. Por esta razão dois 'estágios temporais' (um no passado e outro no presente) foram utilizados na presente análise: 1965 e 2011. O ano de 1965 foi selecionado devido ser o horizonte mais pretérito com disponibilidade de informações acerca do desenvolvimento espacial dos usos do solo e das invasões por espécies não nativas. O ano de 2011 corresponde ao horizonte presente, com disponibilidade de imagens de satélite de alta resolução que permitiram a detecção remota através da fotointerpretação dos contextos dos usos do solo e das invasões por espécies não nativas. O intervalo 1965-2011 pareceu razoável na ordenação dos estágios de tempo, com um adequado período para análise da evolução do uso do solo, bem como para compor a história da invasão biológica local. 


\subsection{Categorização das opções de uso do solo}

Uma paisagem apresenta-se sistematizada sob um mosaico de tipos diferenciados de uso e ocupação do solo, que estão passíveis de serem compartimentados em categorias de detalhe, que por sua vez podem ser agrupadas em unidades gerais. A categorização das opções de uso e ocupação do solo foi realizada de uma escala generalista para uma escala de detalhe, com um 'nível 0 ' (generalista) onde estão concentradas as classes Área social (AS), Área agrícola (AA), Área florestal (AF), e Área de inculto (AI); e 'nível 1' (detalhe) onde estão concentradas as classes Área social (As), Cultura de sequeiro (Ca), Cultura de regadio (Cr), Olival/Pomar (OIPm), Floresta de resinosas (Pn), Floresta de Eucaliptos (Ec), Floresta de outras folhosas (Fof), Incultos (In), e Acacial (Ac). Foram atribuídas 13 classes de uso do solo, sendo 9 categorias de detalhe concentradas em 4 unidades gerais (Tabela I). A sistematização proposta foi elaborada a partir das categorizações estabelecidas pelas cartografias disponíveis do uso do solo. A determinação desta classificação permitiu conhecer, a priori, as limitações e adequações impostas pela natureza e pelas atividades humanas, para o desenvolvimento de processos de invasões biológicas, e, consequentemente, dos graus do processo. As superfícies com espécies não nativas estão representadas pela classe dos Acaciais (Ac), que, por sua vez, estão relacionadas a presença/abundância das espécies, e podem representar ainda co-ocorrências com outras comunidades, destacando as faixas territoriais de comprometimento (alto-médio-baixo) à infestação/invasão por Acácias.

\begin{tabular}{llll}
\hline Usos do solo nível generalista & Simb. & Usos do solo nível de detalhe & Simb. \\
\hline Área social & AS & Área social & As \\
Área agrícola & AA & Cultura arvense de sequeiro & $\mathrm{Ca}$ \\
& & Cultura de regadio & $\mathrm{Cr}$ \\
& & Olival/Pomar & $\mathrm{OIPm}$ \\
Área florestal & AF & Floresta de resinosas & $\mathrm{Pn}$ \\
& & Floresta de Eucaliptos & Ec \\
& & Floresta de outras folhosas & Fof \\
& & Acacial & Ac \\
Área de inculto & Al & Incultos & In \\
\hline
\end{tabular}

Tabela I - Classificação dos usos do solo segundo o nível generalista e de detalhe 


\subsection{Análise espacio-temporal das mudanças do uso e ocupação do solo e das invasões por espécies não nativas}

\section{(i) Análise dos contextos do uso do solo e das invasões no passado}

Cartografias disponíveis para as condições do uso e ocupação do solo no passado foram homogeneizadas de modo a serem utilizadas para análise das mudanças no uso do solo segundo a escala de tempo considerada. Isso foi realizado por digitalização em ambiente SIG das cartas topográficas e mapeamentos do uso do solo disponíveis. Com vistas a obtenção de resultados satisfatórios, certas regras ou restrições foram estabelecidas para que os dados fossem conduzidos sob razoável interpretação visual em ambiente SIG, tendo em vista as diferenças nas resoluções dos documentos cartográficos abordados. Se a qualidade dos dados não permitissem uma similar interpretação visual entre as cartografias, uma comparação com as imagens orbitais para o período presente estaria passível de problemas, sobretudo no âmbito de incongruências.

\section{(ii) Análise dos contextos do uso do solo e das invasões no presente}

A disponibilidade em softwares das condições ambientais podem servir como base para a análise das mudanças do uso do solo no tempo presente. A extensão Basemap, disponibilizada pelo software ArcGIS 10.1, foi selecionada para avaliar o uso do solo e as invasões por espécies não nativas no presente, em razão de incluir imagens de satélite de alta resolução, viabilizando a análise espacial. Para a análise temporal, a evolução, as mudanças e os destinos das diferentes formas de uso do solo, combinado às relações com o histórico das invasões, foram avaliadas por meio do cálculo das áreas ocupadas por cada opção de uso do solo, e posterior interceptação destes valores com auxílio da extensão Intersect do software ArcGIS 10.1. Imagens orbitais de 2011, com alta resolução (resolução $60 \mathrm{~cm})$, e cartografias do uso do solo de 1965, nomeadamente a Carta Agrícola e Florestal de Portugal (escala 1/25000), foram usadas como base para o mapeamento (primeira etapa). Os ortofotomapas disponíveis para 1960 foram usados apenas para efeito da realização das atividades de campo (segunda etapa), para a identificação e aferição das superfícies invadidas, além de posicionamento geográfico com utilização do GPS (sigla em inglês, Global Positioning System). 


\subsection{Análise espacial integrada: uso do solo - invasão - meio físico}

As imagens de satélite georeferrenciadas para a área de estudo são do ano de 2011. Há disponibilidade de cartografias do uso do solo para o ano de 1965, e a combinação das informações advindas do uso do solo, das invasões, e dos condicionantes físicos da paisagem, é aplicável. A análise espacial integrada entre os usos do solo (incluindo incêndios), as invasões, e o meio físico, está explicada nos parágrafos seguintes.

Foi elaborado o mapa de uso e ocupação do solo de 2011 para a Bacia do Rio Arouce, foram homogeneizados os produtos cartográficos no âmbito do uso do solo referentes a 1965 e 2011, e foram verificados os caracteres ambientais da paisagem natural da bacia. A construção dos mapas-base foi feita através da integração dos dados obtidos por meio da fotointerpretação de imagens de satélite de alta resolução (extensão Basemap do software ArcGIS 10.1), e do uso de folhas topográficas e cartografias do uso do solo disponíveis (nomeadamente Carta Agrícola e Florestal de Portugal, 1965, 1/25000).

A elaboração dos mapas-base constou de duas fases. Na primeira, através da fotointerpretação, foi montada uma base para reconhecimento preliminar da área de estudo, sendo delineados canais de drenagem, vias de comunicação (estradas, linhas de alta tensão e corta fogo), a ocupação do solo e suas respectivas opções de uso: antrópicas (espaços urbanos, áreas industriais e áreas de culturas agrícolas), e naturais (áreas de florestas nativas, não nativas e zonas reflorestadas). Esta fase foi realizada antes da etapa de campo (segunda fase) tendo sido importante para a identificação das superfícies invadidas por espécies não nativas. Na segunda fase a área de estudo foi amplamente percorrida, para inspeção dos condicionantes da paisagem e graus das invasões. Percorreram-se os topos das montanhas nas áreas das cabeceiras do Rio Arouce, os vales secos intermitentes do setor intermédio da bacia e suas encostas, além dos barrancos e planícies no setor terminal, área da foz (Figuras 4,5 e 6). Foi verificado que os vales e encostas formados pelas incisões de drenagem que erodiram as rochas do complexo xistograuváquico, apresentam densidade e cobertura siginificativa de plantas invasoras, nomeadamente Acácias, fato verificado sobretudo no setor intermédio da bacia. Por outro lado, os topos dos vales e as planícies de formações rochosas dos terrenos aluvionares, que 
não estão associadas diretamente ao acúmulo de sedimentos da Serra da Lousã, apresentam reduzida densidade de espécies invasoras.

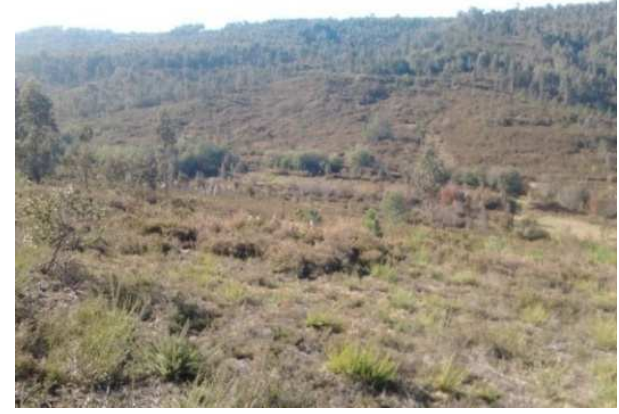

a) Setor terminal (foz)

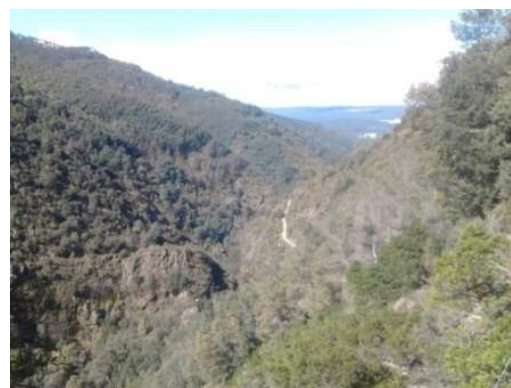

b) Setor intermédio

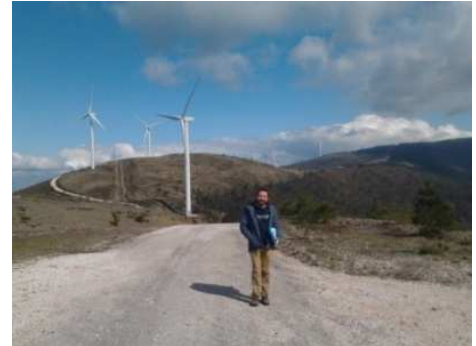

c) Setor cabeceiras

Figuras 4, 5 e 6 - Aspectos da paisagem na Bacia do Rio Arouce

Combinado a análise espacial dos condicionantes físicos (altitude, declive, exposição, rochas, microclimas), a espacialização da ocorrência de incêndios também foi verificada, sendo um dos usos do solo em que a expansão da invasão também parece relacionada. Em todo o país os incêndios tem permitido diminuição das áreas naturais, constituídas por formações florestais nativas, em detrimento do aumento das áreas artificiais, com forte expansão dos incultos e Acaciais, além do significativo aumento do tecido urbano.

O primeiro mapeamento de Acácias para a área de estudo, o mapa do SROA de 1978 (Atlas da Distribuição de Acácias e Eucaliptos, 1/50000), apresenta para a área do baixo Mondego (Figura 7), Bacia do Rio Arouce incluída, povoamentos de Acácias do tipo disperso, apresentando a invasão nos primeiros estágios da escala temporal de análise. 0 mapa da distribuição de Acácias e Eucaliptos não faz discriminação entre as espécies, apenas são indicados os tipos de povoamentos, no qual se entende por povoamento disperso uma superfície em que o número de árvores é superior a 5 por hectare, mas não atinge número suficiente para constituir povoamento dominado. As áreas mínimas de representação no mapeamento do SROA são 20-25ha para povoamentos dominantes e estremes, e 90-100ha para povoamentos dominados. Por isso, embora tenham sido detectados alguns povoamentos do tipo dominantes, extremes e/ou dominados, só há visibilidade no mapa (figura 7) para o povoamento disperso, conspícuo na área de estudo. O registro permite aferir a baixa cobertura/densidade da superfície invadida em 1978, indicando como esteve 
caracterizado o contexto espacial da invasão nos primeiros estágios do recorte temporal considerado (1965-1978).

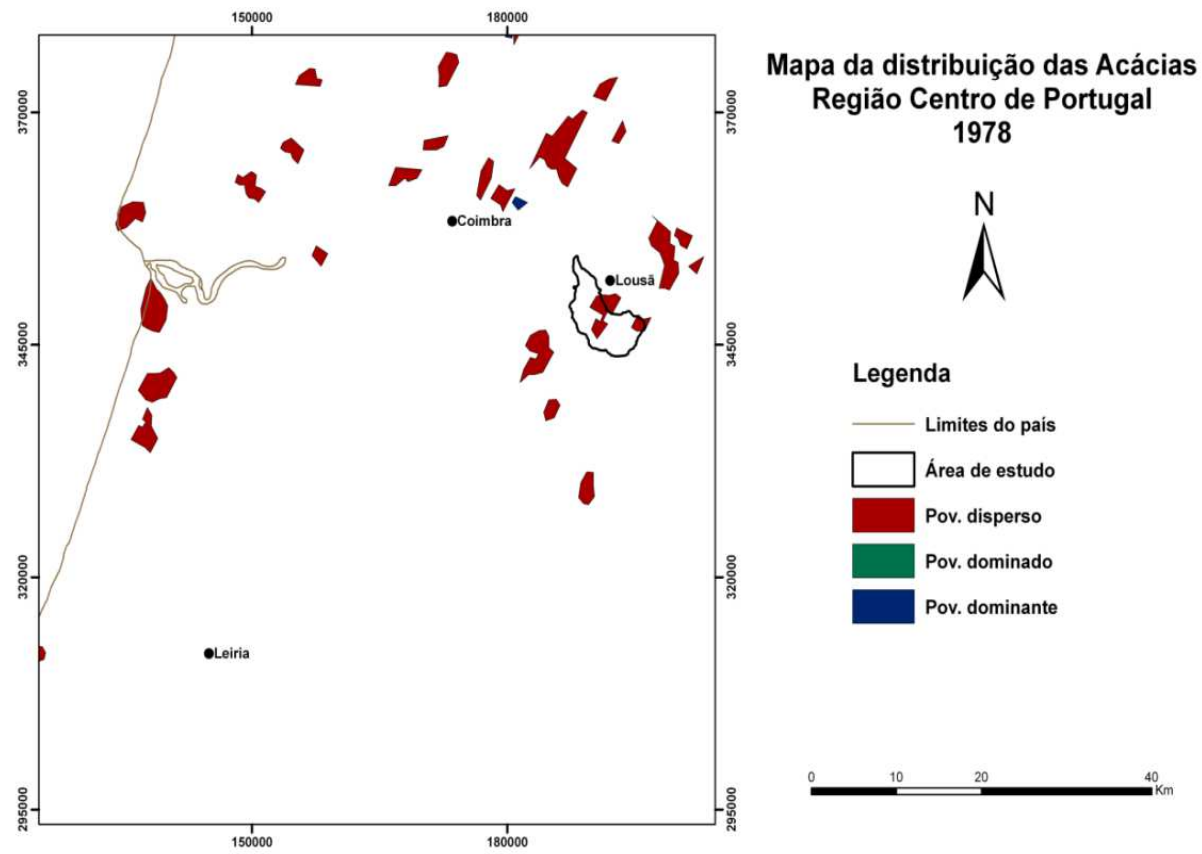

Figura 7 - Mapa dos povoamentos de Acácias no Baixo Mondego em 1978. Fonte: SROA, 1978

\section{Resultados}

A aplicação da metodologia permitiu que as mudanças quantitativas no uso e ocupação do solo pudessem ser analisadas espacialmente. Nos parágrafos a seguir, são detalhadas as análises da evolução, das mudanças, e dos destinos dos usos do solo, descritos de acordo com a sistematização proposta na metodologia.

\subsection{Análise espacial e quantitativa das mudanças no uso do solo}

Os resultados da analise das mudanças nos usos do solo de 1965 para 2011 indicaram uma clara tendência de aumento das (i) áreas sociais (espaços urbanos contínuos, espaços urbanos descontínuos, áreas industriais, vias de comunicação), assim como das (ii) áreas com culturas arvenses de sequeiro, e para as (iii) áreas associadas à presença de espécies não nativas, nomeadamente Acácias (Gráfico I). 
Quanto aos valores de decréscimo obtidos com as mudanças no uso do solo (Gráfico I), estes estiveram referidos sobretudo as (iv) áreas com Florestas de resinosas (Pinhais), (v) áreas com olival/vinha, e as (vi) áreas com culturas agrícolas de regadio, que diminuiram em aproximadamente 12\% suas superfícies originais, de 1965 para 2011.

As mudanças nos usos do solo do tipo (vii) incultos de comunidades herbaceo-arbustivas e (viii) áreas de florestas com outras folhosas, permaneceram relativamente com o mesmo valor apresentado nos dois períodos de análise (Gráfico I). Entretanto, o baixo acréscimo verificado (em torno de 6\%) não significa que estas opções de uso do solo tenham papel secundário no contexto da estrutura da paisagem local. Tanto os incultos como as áreas de florestas com outras folhosas foram e são representativos dos usos do solo com as maiores ocupações na área de estudo, tanto em 1965 como 2011.

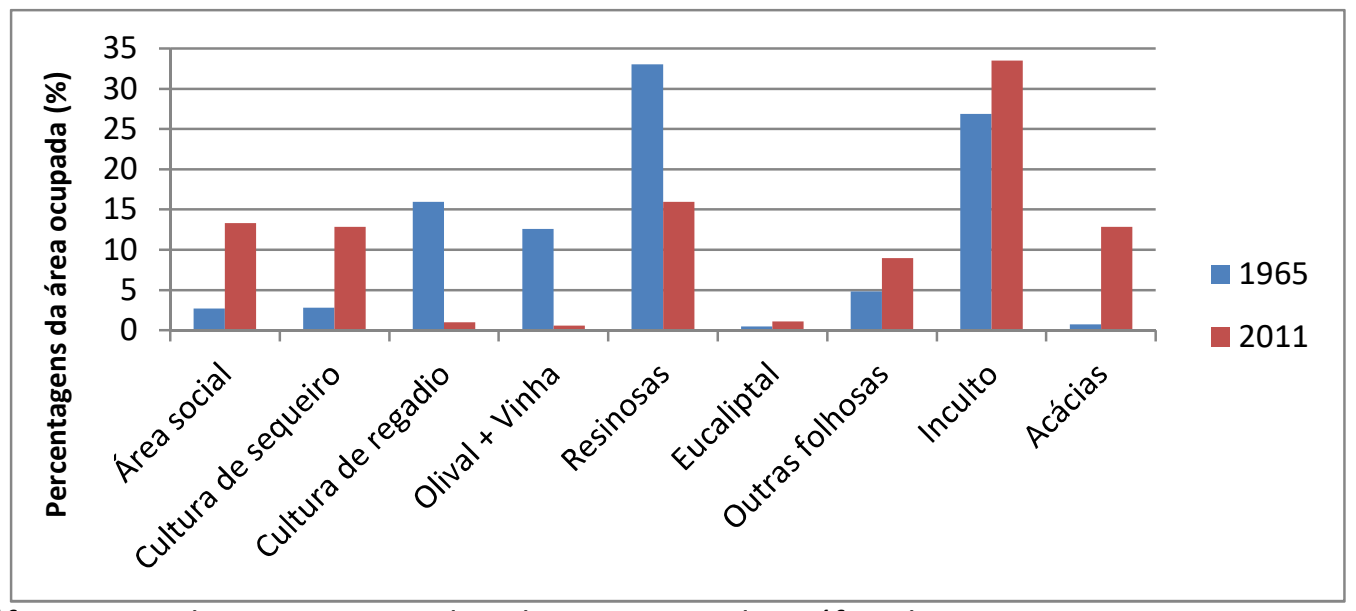

Gráfico 1 - Mudanças nos usos do solo na Bacia Hidrográfica do Rio Arouce entre 1965 e 2011

Considerando as opções de uso do solo que tiveram acrescimos (áreas sociais, culturas arvenses de sequeiro, e áreas com acaciais), o desenvolvimento destes usos tem associação a causas específicas. As áreas sociais cresceram em 10\% entre 1965 e 2011 (Tabela II), de 198,5ha para 972ha, em expansão relacionada ao volume das atividades antropogênicas, sobretudo no sentido de uma maior intensidade no aumento da densidade da rede viária e das vias de comunicação (abertura de estradas e de linhas de alta tensão), contemplando tanto os espaços urbanos contínuos como os espaços urbanos descontínuos (áreas rurais). Essa associação, do aumento das áreas sociais com uma maior densidade da rede viária, foi aferida em campo onde constatou-se uma expansão conspícua das vias de comunicação de norte a sul na área de estudo. 
O desenvolvimento das áreas sociais a partir da abertura de corredores na paisagem (vias de comunicação e linhas de alta tensão) parece ter reflexo na expansão das invasões biológicas por espécies não nativas na área de estudo, nomeadamente espécies de Acácia, sobretudo a espécie Acacia dealbata (Oliveira-Costa, 2014).

\begin{tabular}{|c|c|c|c|c|c|}
\hline \multirow[t]{2}{*}{$\begin{array}{l}\text { Usos } \\
\text { Nível } 0\end{array}$} & \multirow[t]{2}{*}{$\begin{array}{c}\text { Simbologia } \\
\text { Nível } 1\end{array}$} & \multicolumn{2}{|c|}{$\begin{array}{l}\text { Áreas ocupadas (ha) no } \\
\text { recorte temporal } \\
(1965-2011)\end{array}$} & \multicolumn{2}{|c|}{$\begin{array}{l}\text { Áreas ocupadas (\%) no } \\
\text { recorte temporal } \\
(1965-2011)\end{array}$} \\
\hline & & 1965 & 2011 & 1965 & 2011 \\
\hline Sociais & As & 198,579 & 972,034 & 2,719 & 13,310 \\
\hline \multirow[t]{3}{*}{ Agrícolas } & $\mathrm{Ca}$ & 205,252 & 937,724 & 2,811 & 12,840 \\
\hline & $\mathrm{Cr}$ & 1165,881 & 70,622 & 15,965 & 0,967 \\
\hline & OIPm & 917,29 & 42,818 & 12,561 & 0,586 \\
\hline \multirow[t]{4}{*}{ Florestais } & $\mathrm{Pn}$ & 2413,141 & 1165,499 & 33,044 & 15,959 \\
\hline & Ec & 33,936 & 78,726 & 0,465 & 1,078 \\
\hline & Fof & 351,657 & 654,135 & 4,815 & 8,957 \\
\hline & $A c$ & 55,236 & 936,231 & 0,756 & 12,820 \\
\hline Incultos & In & 1961,942 & 2445,125 & 26,865 & 33,481 \\
\hline Total (área & & & $7302,914 \mathrm{ha}$ & & $100 \%$ \\
\hline
\end{tabular}

Tabela II - Valores em hectares e percentagens das mudanças no uso do solo para os níveis 0 e 1 (nível generalista e de detalhe) segundo o recorte temporal 1965-2011

A área das culturas arvenses de sequeiro teve aumento de aproximadamente $10 \%$ para 2011 (Tabela II), de 205ha para 937,7ha de superfície ocupada, caracterizando uma situação excecional dentro do contexto regional, já que a tendência em Portugal é de decréscimo das culturas tradicionais (Nunes et al., 2010, 2011). Essa expansão pode estar relacionada ao caráter extensivo desse uso, e a importância da extensividade das culturas agrícolas arvenses na escala local da área de estudo.

As áreas com presença de espécies não nativas, que possuiam em torno de 55 ha $(0,7 \%)$ em 1965 (Tabela II), tiveram um desenvolvimento surpreendente, expandindo-se para aproximadamente 937ha (13\%) (Tabela II), muito sob reflexo dos resultados das mudanças nos demais tipos de uso do solo: (i) aumento das áreas sociais com expansão da densidade viária (fator determinante na condução de processos de invasão biológica), (ii) diminuição do coberto vegetal com florestas de resinosas (decréscimo dos espaços com componentes 
vegetais que competem espaço com as comunidades não nativas), (iii) expansão das áreas abandonadas ou incultos de comunidades hebáceo-arbustivas (áreas significativamente vulneráveis à invasão por espécies não nativas). Nos parágrafos seguintes, a análise segue em escala de detalhe, com foco nas mudanças nas áreas com presença de Acácias, e suas relações com o meio físico e os incêndios.

\subsection{Análise espacial e quantitativa das invasões biológicas}

Mais específico no âmbito das mudanças nas invasões por espécies não nativas, a presente análise tem recorte espacial restrito, focalizando os espaços invadidos por espécies de Acácia na área de estudo, examinando a relação das mudanças no uso do solo e os condicionantes físicos, com o histórico das invasões locais.

\subsubsection{Contexto 1: uso do solo/invasão em 1965}

Selecionando o contexto 1 (uso do solo/invasão em 1965), é apresentada uma paisagem com baixo grau de infestação das espécies e densidade/cobertura da superfície invadida, com indicação de indivíduos isolados e pequenas áreas invadidas (Figura 8). Em 1965 as Acácias já estavam instaladas, com indicações de pequenas manchas sobretudo nas altitudes médias da bacia (400m-700m) (Figura 8), áreas de pronunciado declive $\left(48^{\circ}\right)$, com disponibilidade de água $(200 \mathrm{~mm})$, e presença de cambissolos espessos com xistos e granitos, e uso do solo predominantemente de formações florestais monoespecíficas (Floresta de resinosas) (Figura 8). O evento de 1965 certamente marcou a passagem da fase lenta para a fase exponencial da invasão, tendo iniciado há aproximadamente 100 anos, e por influência de estímulos, deu início a severa destruição da área dos Pinhais no setor intermédio da bacia, com posterior ocupação desse solo por Acaciais. 

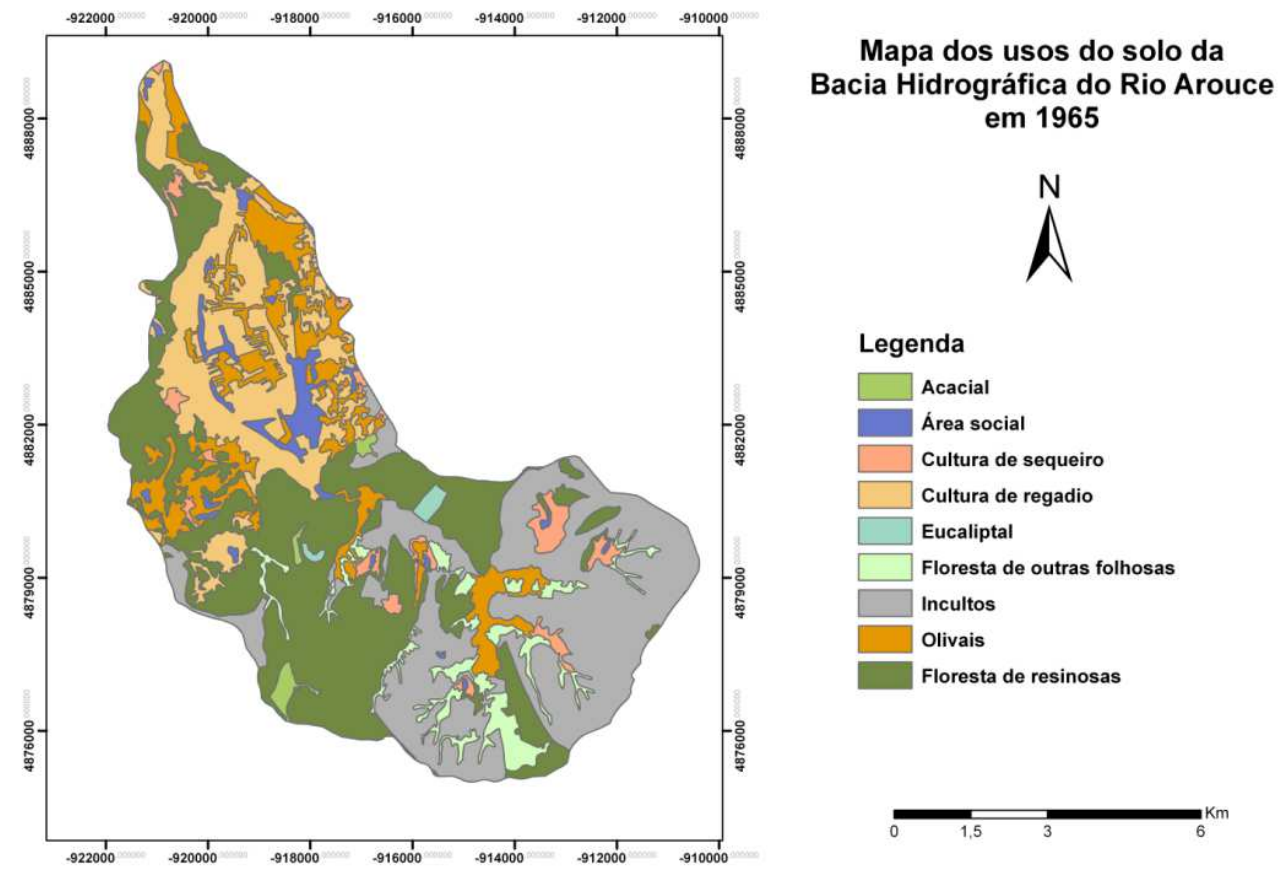

Figura 8 - Mapa do uso do solo na área de estudo/1965. Fonte: Carta Agrícola e Florestal, 1965

\subsubsection{Contexto 2: uso do solo/invasão em 2011}

A evolução para o contexto 2 (uso do solo/invasão em 2011) foi surpreendente, onde o pequeno recorte espacial de áreas invadidas do mapa de 1965 (Figura 8) já não é observado no mapeamento de 2011 (Figura 9), sublinhando que, a partir das pequenas manchas verificadas em 1965, as invasões por Acácia se expandiram de forma agressiva, com alto grau de infestação das espécies e densidade/cobertura da superfície invadida, produzindo grandes manchas (Figura 9). Em 2011 as Acácias já estavam estabelecidas, com indicações de grandes manchas nas altitudes médias da bacia $(400 \mathrm{~m}-700 \mathrm{~m})$, área florestal com maior disponibilidade de água, solos espessos e vales encaixados; pequenas manchas no baixo curso do Rio Arouce $(50 \mathrm{~m}-400 \mathrm{~m})$, planície agrícola com menor disponibilidade de água, solos rasos e declives entre $0^{\circ}-24^{\circ}$; e indivíduos isolados no alto curso $(700 \mathrm{~m}-1200 \mathrm{~m})$, área de pronunciado declive $\left(48^{\circ}\right)$, com disponibilidade de água $(200 \mathrm{~mm})$, presença de cambissolos espessos com xistos e granitos, e uso do solo predominantemente de incultos de comunidades herbáceo-arbustivas (Figura 9). O evento de 2011 compreende a fase exponencial da invasão, tendo essa fase iniciado há 50 anos, e pelo caráter de severidade, promoveu impactos profundos com redução significativa da área original dos Pinhais. As novas áreas invadidas podem ser observadas na Figura 9, indicando um novo uso do solo 'tipo transformador' que surgiu na paisagem, mas que diferente dos demais caracteriza-se como ecologicamente negativo. 

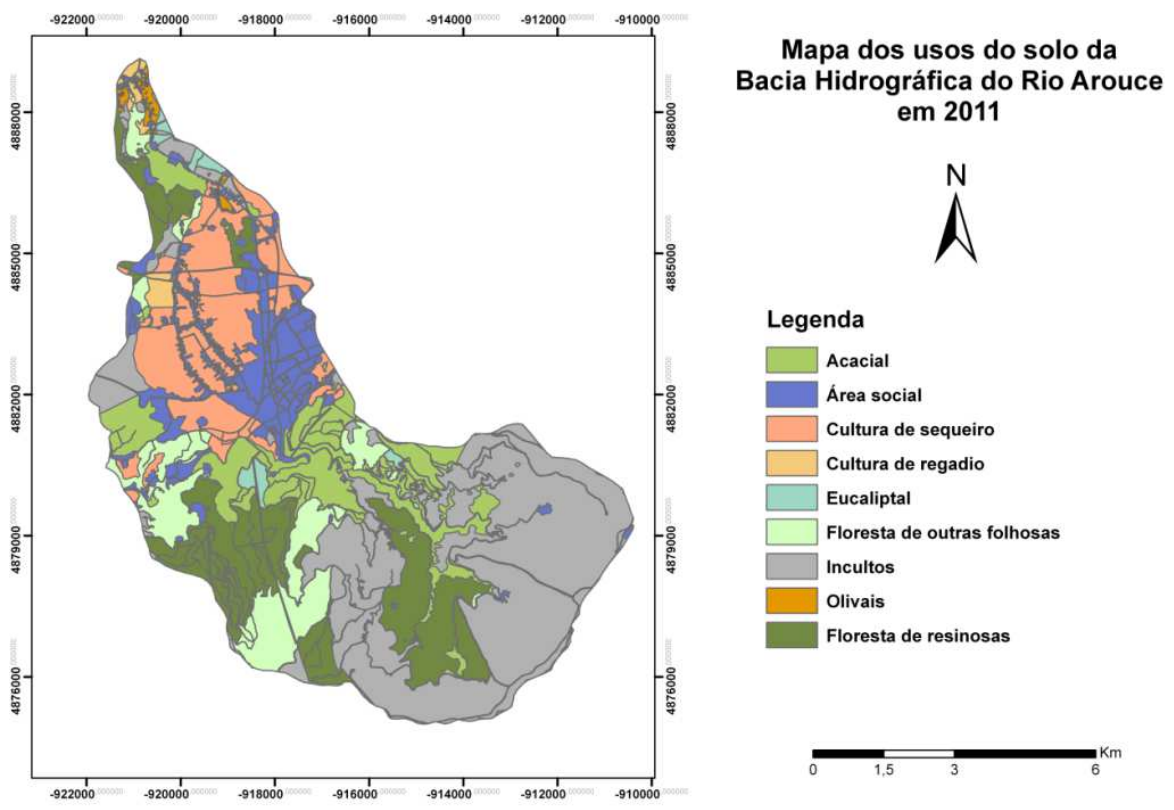
em 2011
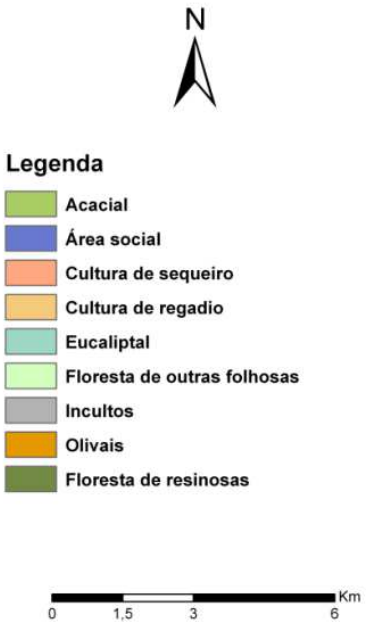

Figura 9 - Mapa do uso do solo na área de estudo/2011. Fonte: Organizado pelos autores, 2011

\subsubsection{Análise integrada: mudanças no uso do solo - invasão - meio físico}

As mudanças nas invasões de 1965 para 2011 mostram um aumento da presença de espécies de Acácia principalmente nos setores intermédio e terminal da área de estudo. Adicionalmente, o decréscimo verificado para as áreas de Florestas de resinosas parece ter associação como o aumento das invasões nestes setores da bacia, pois quando verificado os destinos das superfícies invadidas entre 1965-2011 (Tabela III), observa-se que os maiores valores são da expansão da invasão para as áreas que no passado (1965) pertenciam aos (i) Pinhais (nomeadamente setor intermédio) (Tabela III). A expansão se deu sobretudo do setor da distribuição matriz das Acácias (setor intermédio), rumo ao setor mais baixo topograficamente (setor terminal). Ainda, as mudanças também mostram expansão da invasão para espaços que em 1965 eram cobertos por (ii) Incultos, bem como por (iii) Culturas de olivais/pomares (Tabela III). Apresentam-se assim os três usos com as maiores taxas de perda de superfícies originais para espécies invasoras: (i) Floresta de resinosas, (ii) Incultos e (iii) Culturas de olivais/pomares.

Quanto ao setor cabeceiras, porção espacial mais elevada topograficamente da área da Bacia Hidrográfica do Rio Arouce, um contexto de invasão discrepante do padrão observado à escala da bacia é conspícuo. Nesse setor, dominado especialmente por incultos de comunidades herbáceas e arbustivas, distribuem-se indivíduos isolados e esporáricas manchas de espécies não nativas entre as comunidades naturais. A presença de indivíduos isolados e pequenas áreas de Acácias pode estar relacionada à ocorrência de incêndios nas 
cabeceiras, com registro de episódios de fogo entre 1990 e 1999 (Figura 10), e atividades de lazer off-road, como cycling e motocross, praticadas na área.

\begin{tabular}{lcc}
\hline Usos do solo em 1965 & Área ocupada (ha) por Acácias & Área ocupada (\%) por Acácias \\
\hline Área social & 1,320 & 0,141 \\
Cultura de Sequeiro & 22,784 & 11,101 \\
Cultura de Regadio & 50,904 & 5,437 \\
Olival + Pomar & 128,373 & 13,712 \\
Floresta de Resinosas & 537,413 & 57,402 \\
Floresta de Eucaliptos & 15,886 & 1,697 \\
Floresta de Folhosas & 17,568 & 1,876 \\
Incultos & 149,137 & 15,930 \\
Acacial & 12,846 & 1,372 \\
\hline Total da área invadida em 2011 & $\mathbf{9 3 6 , 2 3 1 h a}$ & $\mathbf{1 0 0 \%}$ \\
\hline
\end{tabular}

Tabela III - Valores em hectares e percentagens das mudanças e destinos dos usos do solo no escopo da área ocupada por Acácias em 2011

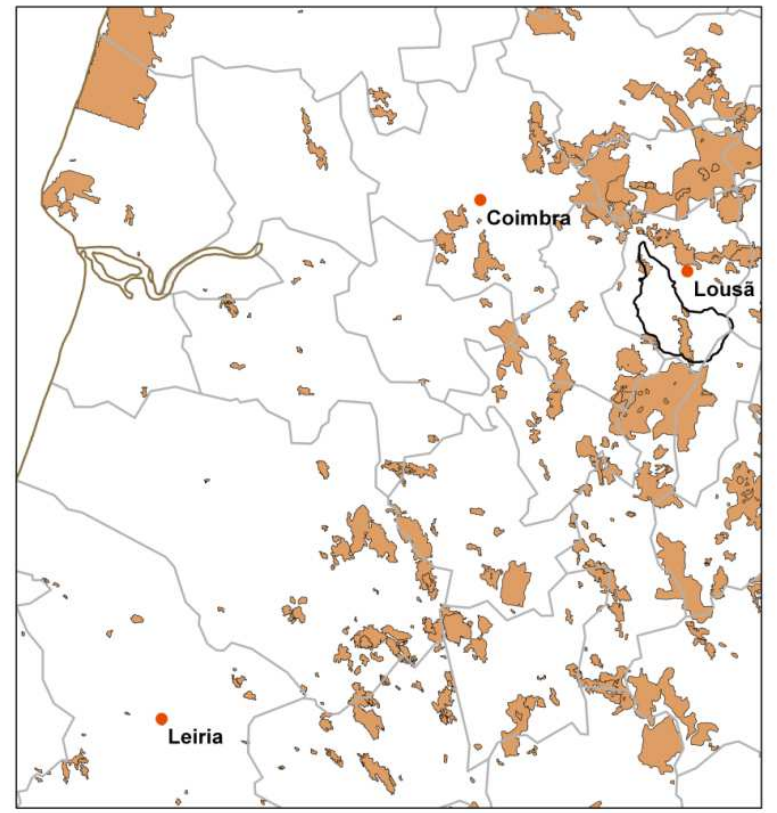
Mapa da ocorrência de incêndios entre 1990 e 1999

Região Centro de Portugal

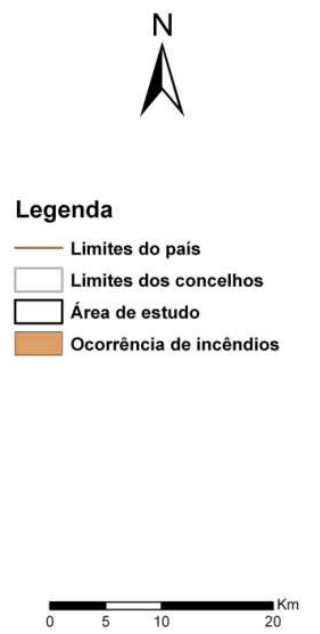

Figura 10 - Mapa da ocorrência de incêndios na área de estudo/anos 90. Fonte: ICNF, 1990-1999

Neste estudo de caso se verificou que o padrão principal da invasão à escala da bacia é caracterizado atualmente por uma instância agressiva do processo no setor intermédio, e por uma instância menos agressiva nos setores terminal e cabeceiras, com presença de pequenas manchas no baixo curso, e indivíduos isolados no alto Rio Arouce.

Os Acaciais de 1965 parecem ter mantido suas áreas, que aumentaram segundo o mapeamento de 2011. Foi verificada manutenção também das áreas florestais de Eucaliptos e de outras folhosas, que estão entre os usos com as menores taxas de perdas de superfícies originais para as Acácias. Florestas com outras folhosas, como castanheiros e carvalhos, 
promovem uma barreira natural às espécies invasoras, destacando a diversidade biótica nas áreas invadidas como uma barreira à invasão (Henderson et al., 2006; Vitousek et al., 1997; Pysek et al., 1995). No caso das Florestas de Eucaliptos, é mais comum observar espécies invasoras co-ocorrendo sob mesmo domínio, entretanto, assim como a diversidade entre nativas, a competitividade entre indivíduos não nativos podem reduzir e até excluir certas comunidades invasoras (Simberloff \& Rejmánek, 2011; Williamson, 1996; Pysek et al., 1995).

Em consonância com a teoria da invasão (Lockwood, 2007; Henderson et al., 2006; Vitousek et al., 1997; Williamson, 1996), as mudanças nos usos do solo, combinado a topografia, a exposição, a declividade, o substrato geológico, o balanço climático, a diversidade biótica, os incêndios, e a gravidade, oportunizam estímulos à expansão da invasão por espécies não nativas na bacia hidrográfica em estudo (Tabela IV).

\begin{tabular}{|c|c|c|c|c|c|c|c|}
\hline \multicolumn{8}{|c|}{ ANÁLISE INTEGRADA DOS CONDICIONANTES FÍSICOS COM A ESTRUTURA DA PAISAGEM NA BACIA DO RIO AROUCE } \\
\hline \multicolumn{8}{|c|}{ CONDICIONANTES FISICOS } \\
\hline Setor da bacia & Altitude (m) & Declive $\left(^{\circ}\right.$ & Exposição & Solos & Geologia & Disponibilidade de água & Vegetação/Uso do Solo \\
\hline Terminal (foz) & $54 \mathrm{~m}-437 \mathrm{~m}$ & $0^{\circ}-24^{\circ}$ & Oeste e Norte & Fluvissolos & $\begin{array}{l}\text { Areias, argilas, arenitos, } \\
\text { cascalhos }\end{array}$ & Condições climatófilas (100mm) & $\begin{array}{c}\text { Uso agrícola, pasto e abandono } \\
\text { da terra }\end{array}$ \\
\hline Intermédio & $437 m-693 m$ & $24^{\circ}-48^{\circ}$ & Sul e Este & Cambissolos & $\begin{array}{l}\text { Xistos, granitos, } \\
\text { cascalhos, areias }\end{array}$ & Condições higrófilas (200mm) & $\begin{array}{l}\text { Zonas mistas com formações } \\
\text { arbóreas monoespecíficas }\end{array}$ \\
\hline Cabeceiras & $693 m-1205 m$ & $48^{\circ}$ & Sul e Oeste & Cambissolos & Xistos, granitos & $\begin{array}{l}\text { Condições mesohigrófilas } \\
\qquad(200 \mathrm{~mm})\end{array}$ & $\begin{array}{l}\text { Incultos de comunidades } \\
\text { herbáceo-arbustivas }\end{array}$ \\
\hline \multicolumn{8}{|c|}{ ESTRUTURA DA PAISAGEM } \\
\hline $\begin{array}{c}\text { Invasões por } \\
\text { Acácias na Bacia } \\
\text { do Rio Arouce }\end{array}$ & $\begin{array}{c}\text { Evento } \\
\text { (Recorte } \\
\text { temporal) }\end{array}$ & $\begin{array}{c}\text { Área } \\
\text { afetada } \\
\text { (Recorte } \\
\text { espacial) }\end{array}$ & $\begin{array}{l}\text { Etapa do processo } \\
\text { à escala da bacia } \\
\text { (Williamson, 1996) }\end{array}$ & $\begin{array}{l}\text { Grau das espécies } \\
\text { à escala da bacia } \\
\text { (Williamson, 1996) }\end{array}$ & $\begin{array}{c}\text { Estrutura da paisagem e } \\
\text { invasões à escala do setor } \\
\text { terminal (zona urbana e } \\
\text { planície agrícola/50m-400m) }\end{array}$ & $\begin{array}{c}\text { Estrutura da paisagem e } \\
\text { invasões à escala do setor } \\
\text { intermédio (zona florestal } \\
\text { monoespecífica/400m-700m) }\end{array}$ & $\begin{array}{c}\text { Estrutura da paisagem e } \\
\text { invasões à escala do setor } \\
\text { cabeceiras (zona de incultos de } \\
\text { comunidades herbáceas e } \\
\text { arbustivas/700m-1200m) }\end{array}$ \\
\hline $\begin{array}{l}\text { Acácias invasoras } \\
\text { na Bacia do Rio } \\
\text { Arouce na } \\
\text { segunda metade } \\
\text { do século XX }\end{array}$ & $\begin{array}{c}\text { Invasões } \\
\text { por Acácias } \\
\text { em } 1965\end{array}$ & $\begin{array}{l}55,236 \mathrm{ha} \\
(0,7 \% \mathrm{da} \\
\text { área total })\end{array}$ & $\begin{array}{c}\text { Estabelecimento: } \\
\text { final da fase lenta } \\
\text { (1910-1965) }\end{array}$ & $\begin{array}{l}\text { Acácias invasoras } \\
\text { (dispersão pontual) }\end{array}$ & $\begin{array}{l}\text { Baixo grau de infestação com } \\
\text { indivíduos isolados oriundos do } \\
\text { setor intermédio, associação a } \\
\text { proximidade da calha do Rio } \\
\text { Arouce e cursos adjacentes }\end{array}$ & $\begin{array}{l}\text { Distribuição matriz das Acácias } \\
\text { com médio grau de infestação, } \\
\text { presença de pequenas manchas } \\
\text { associadas as condições do relevo } \\
\text { (vales encaixados), do clima } \\
\text { (condições climatófilas), do solo } \\
\text { (solos espessos com xisto e } \\
\text { granito), e diversidade biótica } \\
\text { (formações monoespecíficas } \\
\text { sobretudo de Resinosas) }\end{array}$ & $\begin{array}{l}\text { Presença não identificada de } \\
\text { Acácias ou de esporádicos } \\
\text { indivíduos isolados. Caracteres } \\
\text { como a altitude (1200m) } \\
\text { dificultam a chegada e } \\
\text { propagação das Acácias nesse } \\
\text { setor da bacia. Os indivíduos } \\
\text { isolados presentes não } \\
\text { aumentaram em populações, } \\
\text { mas mantiveram-se. }\end{array}$ \\
\hline $\begin{array}{c}\text { Acácias } \\
\text { transformadoras } \\
\text { na Bacia do Rio } \\
\text { Arouce no } \\
\text { período corrente }\end{array}$ & $\begin{array}{l}\text { Invasões } \\
\text { por Acácias } \\
\text { em } 2011\end{array}$ & $\begin{array}{l}936,231 \mathrm{ha} \\
(12,8 \% \mathrm{da} \\
\text { área total) }\end{array}$ & $\begin{array}{c}\text { Naturalização: } \\
\text { fase exponencial } \\
\text { (1965-2011) }\end{array}$ & $\begin{array}{c}\text { Acácias } \\
\text { transformadoras } \\
\text { (dispersão difusa) }\end{array}$ & $\begin{array}{c}\text { Médio grau de infestação com } \\
\text { pequenas manchas, dispersão } \\
\text { proveninente do setor intermédio, } \\
\text { associação ao aumento das áreas } \\
\text { sociais (corredores) e de sequeiro }\end{array}$ & $\begin{array}{l}\text { Distribuição matriz das Acácias } \\
\text { com alto grau de infestação do } \\
\text { tipo transformador, presença de } \\
\text { grandes manchas com associação } \\
\text { a severa redução das áreas de } \\
\text { Resinosas, que perderam solos } \\
\text { com a expansão dos Acaciais }\end{array}$ & $\begin{array}{l}\text { Baixo grau de infestação com } \\
\text { presença de indivíduos isolados } \\
\text { nas encostas declivosas }\left(48^{\circ} \text { ) da }\right. \\
\text { cota de altitide } 700 \mathrm{~m} \text {. Possível } \\
\text { associação às atividades de lazer } \\
\text { off-road (cycling, motocross) na } \\
\text { área, e como resultado de } \\
\text { atividades de incêndios. }\end{array}$ \\
\hline
\end{tabular}

Tabela IV - Mudanças nos usos do solo, condicionantes físicas e invasões sob análise integrada 


\section{Discussão e Conclusões}

Os resultados dessa análise mostraram dois diferentes contextos: o desenvolvimento do uso do solo e invasões em 1965/o desenvolvimento do uso do solo e invasões em 2011. Em ambos os contextos, uma inclinação à invasão foi detectada, entretanto a natureza dos fatores determinantes em cada recorte temporal foi diferente, o que permitiu a identificação de dois contextos da invasão biológica. Na Tabela $\mathrm{V}$, a natureza dos fatores determinantes como estímulo à expansão das invasões é explicada através da análise dos destinos dos usos do solo segundo o recorte temporal considerado (1965-2011). Na sequencia, serão salientados os principais resultados obtidos, integrando-os no contexto de outras referências bibliográficas que abordam a teoria em foco.

Antes de tudo, é necessário salientar que os mapeamentos produzidos para os anos de 1965 e 2011 estão passíveis de incongruências, dado questões como a interpretação visual realizada, além das resoluções diferentes dos documentos cartográficos considerados, com melhor qualidade da imagem aérea de 2011 (ArcGIS), quando comparada à qualidade da cartografia do uso do solo de 1965 (CAF).

Os resultados da análise do contexto do uso do solo e da invasão entre 1965-2011 mostraram acentuadas mudanças, nomeadamente com aumento das superfícies com culturas arvenses de sequeiro (agricultura), além das áreas urbanas contínuas e descontínuas (expansão humana), sobretudo nos setores com declividade acentuada da porção intermédia da bacia, e nas áreas menos elevadas da planície sedimentar e dos terrenos aluvionares do setor terminal, com expansão dos Acaciais nesses solos.

A agricultura e a expansão humana estão entre as principais atividades humanas com geração de estímulos às invasões biológicas (Lockwood, 2007; Williamson, 1996). A tradição agrícola e consequente fragmentação/perturbação produzida com o seu desenvolvimento na área da Bacia do Rio Arouce, poderá ter conduzido a redução temporal no âmbito da sucessão vegetal das comunidades naturais (Pysek et al., 1995), sobretudo nas unidades ambientais intermédia e terminal da área, gerando impactos também nas funções dos ecossistemas, nomeadamente no balanço hídrico-climático, no contexto dos decompositores e produtores primários e secundários, até o substrato litológico-pedológico (Simberloff \& Rejmánek, 2011). Desde o momento da seleção das Acácias para cultivo na 
área da Bacia do Rio Arouce (Introdução), até hoje para escolha dos locais adequados de reprodução, dispersão, e distribuição populacional (estabelecimento-naturalização), aspectos como os padrões de concentração dos recursos na área da bacia (sombreamento, humidade), os efeitos topográficos (altitide, declividade, exposição), a localização geográfica (alto, médio, baixo curso), e a estrutura da paisagem (usos do solo), são traços determinantes, estimulando a sobrevivência dos propágulos das $\mathrm{EEI}$, a reprodução sustentável e dispersão difusa por toda a área afetada, com surgimento de ordens adicionais de estabelecimento de novas colônias (Henderson et al., 2006). A seleção das unidades intermédia e terminal da bacia, sob gradiente topográfico dos 700m com declives acentuados à planície sedimentar com declive de $0^{\circ}$, mostra a contribuição desses traços à actual dimensão espacial das espécies invasoras.

\subsection{Contexto 1: uso do solo/invasão em 1965}

O contexto do uso do solo em 1965 sofreu com decréscimos nas áreas florestais, sobretudo de Florestas de resinosas (Pinhais), e nas culturas agrícolas, como as culturas de regadio, em oposição ao aumento das superfícies com espécies não nativas, nomeadamente Acácias, e das áreas com culturas tradicionais, como a cultura de sequeiro (Tabela V). No caso das áreas sociais, houve uma evolução positiva de $13 \%$ na área da Bacia do Rio Arouce (Tabela V). Os dados sobre os destinos desse uso mostram que os atuais 972 ha pertenciam em 1965 sobretudo a culturas agrícolas de regadio e culturas de olivais/pomares (Tabela V). Foram obtidos valores representativos no âmbito da evolução das áreas com culturas de sequeiro (Tabela V), como um dos usos do solo que tiveram maior desenvolvimento na área de estudo. Os destinos desse uso mostram que seu domínio atual contemplava em 1965 áreas com culturas de regadio e culturas de olivais/pomares (Tabela V). Desse modo, as duas das mais significativas mudanças no uso do solo que ocorreram na área de estudo, indicam substituição de áreas agrícolas de regadio e olivais/pomares por áreas sociais e culturas arvenses. 


\subsection{Contexto 2: uso do solo/invasão em 2011}

Em contraste com o contexto anterior, o contexto do uso do solo de 2011 apresentou um significativo acréscimo da superfície invadida por espécies não nativas, ocupando áreas que no contexto de 1965 pertenciam sobretudo a espaços com Florestas de resinosas (Tabela V). Esse significativo acréscimo da superfície invadida é resultado do aumento nas atividades humanas, que tiveram espaços sociais e agrícolas acrescidos consideravelmente. Mesmo com diminuição das áreas de regadio (Tabela V), se verificou em 2011 culturas tradicionais (nomeadamente a cultura arvense de sequeiro) distribuindo-se especialmente pelo setor intermédio da bacia e à jusante próximo à foz. Em oposição a diminuição das áreas com regadio, houve aumento nas áreas sociais e florestais, sobretudo com espécies não nativas. A análise sequencial do destino dos usos do solo indicou variação significativa ao nível da ocupação, com redução das áreas agrícolas e das áreas com florestas de resinosas (Tabela V), em oposição ao desenvolvimento significativo das áreas com acaciais, das áreas sociais e dos incultos (Tabela V), embora tenha havido ligeiro acréscimo nas áreas de florestas de folhosas (carvalhais e castanheiros), e acréscimo significativo nas culturas de sequeiro.

\begin{tabular}{|c|c|c|c|c|c|c|c|c|c|c|}
\hline \multicolumn{2}{|c|}{ Usos em 1965} & \multicolumn{9}{|c|}{ Mudanças dos usos do solo na série histórica (1965-2011) } \\
\hline Tipo & ha & As & $\mathrm{Ca}$ & $\mathrm{Cr}$ & OlPm & Pn & Ec & Fof & In & Ac \\
\hline As & 198,579 & 165,444 & 15,506 & 2,203 & 1,338 & 5,480 & - & 1,301 & 5,988 & 1,320 \\
\hline $\mathbf{C a}$ & 205,252 & 23,625 & 23,724 & 2,924 & - & 22,750 & - & 16,744 & 92,700 & 22,784 \\
\hline $\mathbf{C r}$ & 1165,881 & 298,485 & 574,022 & 59,716 & 8,254 & 48,718 & 2,530 & 44,884 & 78,368 & 50,904 \\
\hline OIPm & 917,290 & 248,662 & 288,966 & 3,913 & 32,529 & 70,326 & 3,003 & 81,129 & 60,388 & 128,373 \\
\hline Pn & 2413,141 & 159,178 & 29,561 & 1,866 & 0,697 & 656,421 & 64,111 & 416,841 & 547,053 & 537,413 \\
\hline Ec & 33,936 & 1,761 & - & - & - & 8,145 & 6,594 & 1,550 & - & 15,886 \\
\hline Fof & 351,657 & 8,798 & - & - & - & 134,241 & - & 25,346 & 165,704 & 17,568 \\
\hline In & 1961,942 & 64,536 & 5,945 & - & - & 215,577 & - & 33,927 & 1492,820 & 149,137 \\
\hline Ac & 55,236 & 1,545 & - & - & - & 3,841 & 2,488 & 32,413 & 2,104 & 12,846 \\
\hline Total & 7302,914 & 972,034 & 937,724 & 70,622 & 42,818 & 1165,499 & 78,726 & 654,135 & 2445,125 & 936,231 \\
\hline
\end{tabular}

Tabela V - Valores em hectares das mudanças no uso do solo e superfícies invadidas com detalhamento das áreas destino e seus valores segundo o recorte 1965-2011 
O complexo e dinâmico desenvolvimento das mudanças nos usos do solo tiveram efeito no desenvolvimento das superfícies invadidas por espécies não nativas, ligando-se à aspectos de ordem natural e humana, seguindo a aplicabilidade da Teoria da Invasão Biológica (Lockwood, 2007; Vitousek et al., 1997; Williamson, 1996). No contexto em epígrafe, as mudanças nos usos do solo são fatores chave para essa análise espacial. Entretanto, a importância das consequencias dos processos das invasões biológicas é pouco esclarecida no estudo de caso, pelo fato da análise das mudanças no uso do solo não produzir resultado suficiente a ponto de mensurar essas consequencias.

Considerando o caráter preditivo, a tendência das superfícies invadidas por espécies não nativas parece ser de aumento progressivo, em curto intervalo de tempo, sendo uma indicação para implicações futuras sobretudo no âmbito das áreas florestais que competirão espaço com as não nativas, podendo trazer profundos impactos aos ecossistemas. Análises geográficas no âmbito das invasões devem produzir mapas direcionados à modelos de padrões espaciais da invasão, que poderão avaliar cenários de risco às invasões. O estudo produzido pela presente pesquisa, com análise das mudanças no uso do solo e efeito nas invasões por espécies não nativas, combinado a estudos futuros de compreensão de riscos e cenários de invasão, poderão subsidiar ações ligadas ao desenvolvimento sustentável e conservação da natureza a nível local.

\section{Referências bibliográficas}

ELTON, C.S. (1958). The ecology of invasions by animals and plants. Methuen, London.

FRIDLEY J. D. (2011). "Invasibility of communities and ecosystems". In: D. Simberloff and M. Hejmanek editors. Encyclopedia of Biological Invasions. University of California Press, London.

GALLIEN L., MÜNKEMÜLlER T., ALBERT C. H., BOULANGEAT I., \& THUILLER W. (2010). “Predicting potential distributions of invasive species: where to go from here?" Diversity and Distributions: 16: 331-342.

GUO, Q. F. (2006). "Intercontinental biotic invasions: what can we learn from native populations and habitats?" Biological Invasions: 8: 1451-1459.

HENDERSON, S. et al. (2006). "Progress in invasive plants research". Progress in Physical Geography: 30, 1. pp. 25-46. 2006.

IUCN [International Union for the Conservation of Nature]. (1999). "IUCN guidelines for the prevention of biodiversity loss due to biological invasion". Species: 31/32: 28-42. 
LEVINE, J. M., VILA, M., D’ANTONIO, C., DUKES, J. S., GRIGULIS, K. \& LAVOREL, S. (2003). “Mechanisms underlying the impact of exotic plant invasions". Phil. Trans. Roy. Soc., 270, 775-781.

LOCKWOOD, J. L. et. al. (2007). Invasion Ecology. Blackwell Publishing.

MACDONALD, G. (2003) Biogeography: Introduction to Space, Time and Life. Willey, $1^{\circ}$ edition.

NUNES, A. N. et. al. (2010). "Soil erosion and hydrological response to land abandonment in a central inland area of Portugal". Land Degradation \& Development. 21: 260-273.

NUNES, A. N. et. al. (2011) "Impacts of land use and cover type on runoff and soil erosion in a marginal area of Portugal”. Applied Geography: 31, 687-699.

OLIVEIRA-COSTA, J. L. P. (2014). “Os Caminhos da Invasão do Género Acacia Mill. na Bacia do Rio Arouce”. Tese de Mestrado. Faculdade de Letras/Universidade de Coimbra.

OLIVEIRA-COSTA, J. L. P. \& SOUZA, R. J. (2015). “Organização geossistêmica e invasões por Acacia sp. (Fabaceae: Mimosoideae) na Bacia Hidrográfica do Rio Arouce. Uma visão das invasões biológicas à escala do geossistema". Revista de Geografia e Ordenamento do Território: 8: 145-169.

PEREIRA, J. \& FIGUEIREDO, A. (2015). "Assessing suitable area for Acacia dealbata Mill. in the Ceira River Basin (Central Portugal) based on maximum entropy modelling approach". Revista de Geografia e Ordenamento do Território: 8: 171-190.

PIMENTEL, D. ET. al. (2005). "Update on the environmental and economic costs associated with alien-invasive species in the United States". Ecological Economics. 52: 273-288.

PYSEK, P., REJMÁNEK, M., PRANCH, K. \& WADE, M. (1995). Plant invasions - general aspects and special problems. Netherlands, Academic Publishing Amsterdam, Amsterdam, 713p.

REJMÀNEK, M. (2011). “Invasiveness". In: Simberloff D. \& Rejmánek M. (eds.) Encyclopedia of Biological Invasions. University of California Press, Berkeley.

RICHARDSON, D. M. \& PYSEK, P. (2006). "Plant invasions: merging the concepts of species invasiveness and community invasibility". Progress in Physical Geography: 30: 409-431.

RICHARDSON, D. M. et. al. (2011). "Human-mediated introductions of Australian acacias-a global experiment in biogeography". Diversity and Distribution: papers editorial.

SIMBERLOFF, D. \& REJMÁNEK, M. (2011). Encyclopedia of Biological Invasions. University of California Press, Berkeley \& Los Angeles.

SHIGESADA, N. \& KAWASAKI, K. (1997). Biological invasions - Theory and pratice. Great Britain, Oxford University Express, Oxford, 204p.

WATTS, D. (1971). Principles of Biogeography: an introduction to the functional mechanisms of ecosystems. McGraw-Hill Publishing Co. Ltd.

WILLIAMSON, M. (1996). Biological invasions. Chapman \& Hall Publishing, London, 244p.

VAVILOV, N. I. (1992). Origin and geography of cultivated plants. Great Britain, Cambridge University express, Cambridge. 497p.

VITOUSEK, P. M. et. al. (1997). "Introduced species: A significant component of human-caused global change". New Zealand Journal of Ecology: 21: 1-16. 